К. В. Базіло, к.т.н., доиент,

В. М. Заїка, к.m.н.,

Ю. Ю. Бондаренко, к.т.н., доцент

Черкаський державний технологічний університет

б-р Шевченка, 460, м. Черкаси, 18006, Україна

\title{
РОЗРОБКА СИСТЕМИ ЗНЕЗАРАЖЕННЯ УЛЬТРАЗВУКОВОГО ХІРУРГІЧНОГО ІНСТРУМЕНТУ
}

Пошук і розробка методів зниження крововтрати, прискорення загоєння післяоперачійних ран і розсмоктування рубців є важливими завданнями сучасної хірургї̈, перспективним розв'язанням яких є застосування ультразвукової хірургї̈ з використанням п'єзоелектричних елементів, котрі відіграють роль джерел ультразвуку. Під час використання ультразвукового хірургічного інструменту актуальною задачею є його дезінфекція до та після проведення опеpauıiu.

Метою роботи є розробка методу дезінфекиії для знищення збудника інфекції на ріжучій частині ультразвукового хірургічного інструменту.

В роботі розроблено схему та проведено моделювання перетворювача напруги для ультрафіолетових випромінювачів, сконструйовано док-станиію для мобільного ультразвукового хірургічного інструменту для його заряджання та процесу дезінфекиії. Розроблено модель ультразвукового хірургічного інструменту та методику дезінфекції для знищення збудника інфекиї̈ на ріжучій частині ультразвукового хірургічного інструменту.

Розроблений хірургічний інструмент є мобільним та автономним, що забезпечується иляхом використання Li-ion акумуляторів, надійним та має значний строк служби активних елементів з п'єзокераміки, зручним в експлуатації та простим у керуванні за рахунок використання ергономічної рукоятки.

Ключові слова: ультразвук, хірургічний інструмент, ультрафіолетове випромінювання.

Вступ. Поширеність вогнепальних поранень пов'язана з криміналізацією суспільства, терористичними загрозами, збільшенням кількості локальних військових конфліктів і громадських заворушень [1]. Основним методом попередження розвитку важких інфекційних ускладнень вогнепальних поранень $\epsilon$ операція - первинна хірургічна обробка ран [2]. Перспективним $€$ застосування ультразвукової хірургії з використанням п'єзоелектричних елементів, котрі відіграють роль джерел ультразвуку [3, 4].

Питання забезпечення населення України якісним хірургічним обладнанням $є$ важливою складовою забезпечення конституційного права громадян на охорону здоров'я (стаття 49 Конституції України).

Під час використання ультразвукового хірургічного інструменту актуальною задачею $\epsilon$ його дезінфекція до та після проведення операцій.
Публікація містить результати досліджень, проведених за грантом Президента України за конкурсним проектом № GP/Ф75/201/2018 Державного фонду фундаментальних досліджень.

Метою роботи $\epsilon$ розробка методу дезінфекції для знищення збудника інфекції на ріжучій частині ультразвукового хірургічного інструменту.

На рис. 1 зображено модель мобільного ультразвукового хірургічного інструменту.

Основними перевагами запропонованого хірургічного інструменту є його мобільність та автономність, що забезпечується шляхом використання Li-ion акумуляторів, надійність і значний строк служби активних елементів 3 п'єзокераміки, зручність в експлуатації та простота в керуванні за рахунок використання ергономічної рукоятки. 


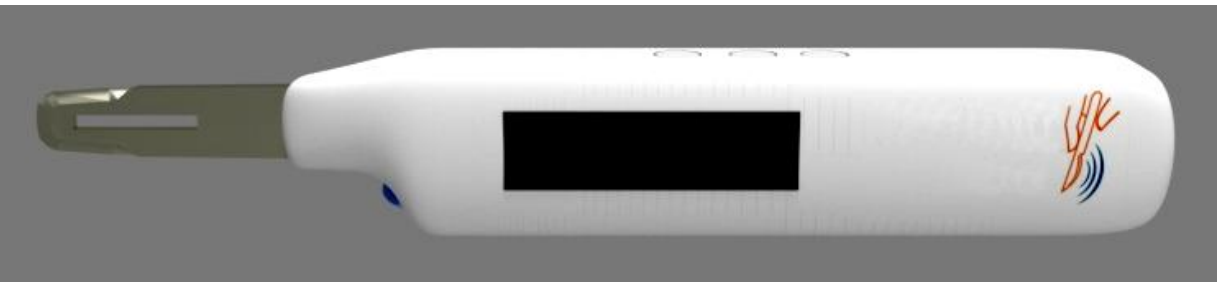

Рис. 1. Модель мобільного ультразвукового хірургічного інструменту

Бактерицидний ефект дозволяє використовувати просту і оригінальну методику самостерилізаціі хірургічного інструменту. При зануренні в розчин дезінфектанту ультразвукові коливання викликають інтенсивні мікротечії рідини поблизу інструменту, очищаючи його поверхню. Крім того, збільшуючи проникність мембран клітин хвороботворних бактерій відносно дезінфікуючої речовини, ультразвук підвищує ефективність ії дії, що дозволяє на порядок знизити концентрацію цієї речовини в розчині.

Амплітуда коливань хвиль ріжучої частини інструменту може становити від 1 до 365 мкм (залежно від призначення інструменту і потреб операції), частота - від 20 до 100 кГц. Ультразвукові коливання зменшують тертя між тканинами і лезом. Як відомо, тертя спокою більше, ніж тертя ковзання, тому тертя між двома поверхнями зменшується, якщо одна 3 них здійснює коливальні рухи. Саме тому робота $з$ ультразвуковими інструментами вимагає від хірурга менших зусиль.

При розсіченні м'яких тканин ультразвуковим інструментом, лезо якого здійснює поздовжні ультразвукові коливання, з тканиною взаємодіє лише кромка леза, забезпечу- ючи процес мікрорізання, що суттєво підсилює ріжучі властивості інструменту. Крім того, біля кромки леза інструменту, який коливається, виділяється теплота, яка локально підвищує температуру тканини і обумовлює гемостатичний ефект в результаті термокоагуляції крові [5].

Під час проведення дезінфекції знищуються в основному патогенні мікроорганізми, що відрізняється від стерилізації, при якій знищуються всі види мікроорганізмів і їх спори.

Променеві засоби знезараження - це застосування сонячного світла, ультрафіолетових променів, радіоактивного випромінювання. Ультрафіолетові промені згубно діють на багатьох збудників інфекційних захворювань. Особливо чутливі до них збудники дизентерії, черевного тифу. Тому цей вид дезінфекції ріжучої частини хірургічного інструменту $€$ найбільш раціональним, тому що може застосовуватися поза межами стаціонарних медичних пунктів, а особливо в екстремальних умовах. На рис. 2 зображено схему перетворювача напруги, який живить два послідовно з'єднані ультрафіолетові світлодіоди.

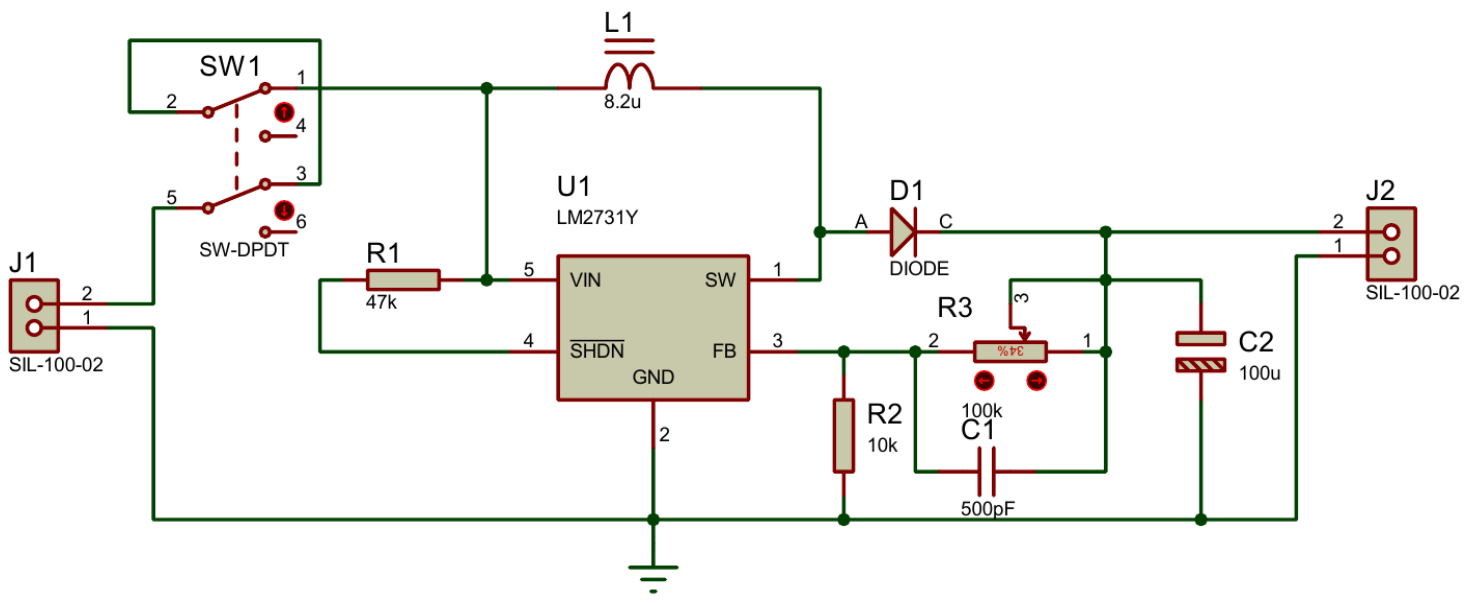

Рис. 2. Схема електрична принципова перетворювача напруги

Зовнішній вигляд портативного перетворювача напруги DC-DC Step-up $\left(\mathrm{U}_{\text {жив }}=4,2 \mathrm{~B}\right.$, $\mathrm{UDC}-\mathrm{DC}=7,2$ B) зображено на рис. 3 . 

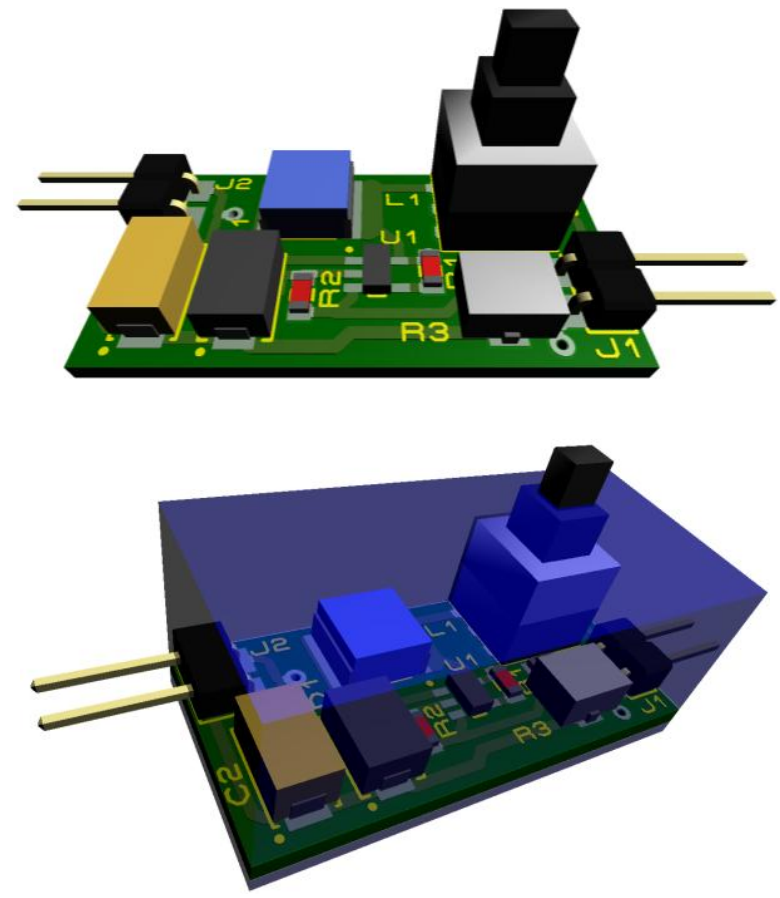

Рис. 3. Зовнішній вигляд портативного перетворювача напруги DC-DC Step-up

Перетворювач напруги, який зображено на рис. 2, побудований на мікросхемі LM2731Y, що працює на частоті 600 кГц і має значний запас потужності та здатна підтримувати силу струму на рівні 4 A.

Основні характеристики ультрафіолетового світлодіода UV-LED-365nm:

- максимальний струм - 0,7 A;

- максимальна потужність - 3 Вт;

- номінальна пряма напруга - 3,7 B;

- кут поширення променів - $120^{\circ}$;

- довжина хвилі - 365 нм.

Для зменшення кута освітлення необхідна фокусуюча лінза, котра збирає весь потік світла в пучок і направляе в потрібному напрямку. Необхідне рівномірне освітлення ріжучої частини хірургічного інструменту досягається застосуванням спеціальних матеріалів, розсіюючих поверхонь і коригуванням форм елементів фокусуючої лінзи та їх розташування.

Параметри відбивачів обчислюються 3 урахуванням кута огляду і діаграми спрямованості світлодіода, розміру об'єкта і відстані до нього, а також необхідного розподілу освітленості об'єкта.

На рис. 4 зображено док-станцію для мобільного ультразвукового хірургічного інструменту. На внутрішній панелі докстанції розміщені ультрафіолетові випромінювачі для знезараження інструменту під час зарядки.

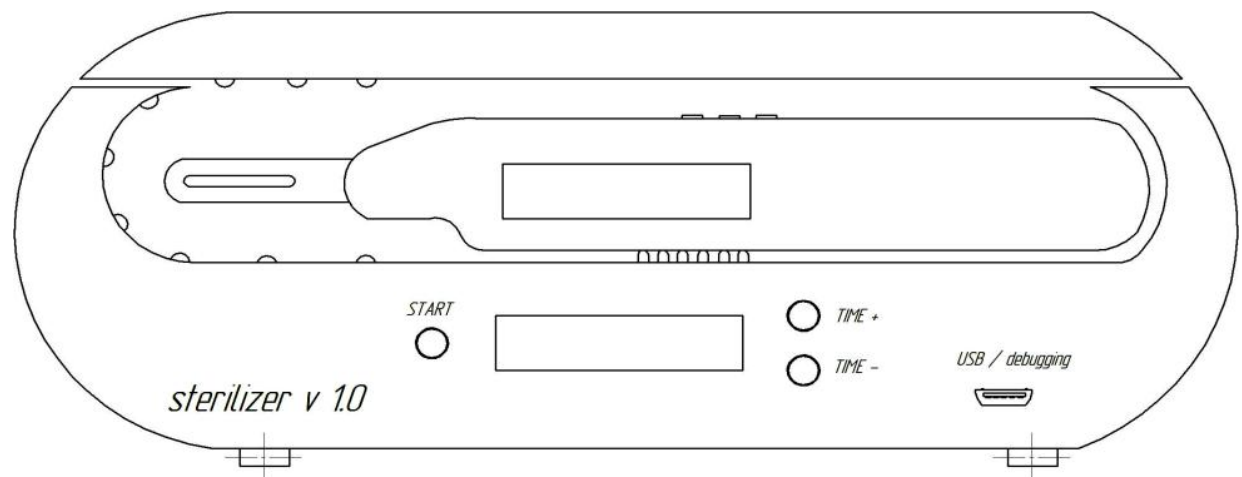

Рис. 4. Док-станція мобільного ультразвукового хірургічного інструменту

«Docking station» в перекладі 3 англійської означає «станція для стикування». Док- станція - це особлива конструкція, яка приєднується до мобільного ультразвукового хірур- 
гічного інструменту за допомогою групи роз'ємів для розширення функціональних можливостей. Після того, як ультразвуковий хірургічний інструмент є підключеним до док-станції, разом вони складають єдин готовий пристрій.

Док-станція, як підставка для ультразвукового хірургічного інструменту, дозволяе синхронізувати дані з підключеним до нього пристроєм, наприклад 3 настільним комп'ютером і одночасно заряджати акумулятор та виконувати стерилізацію.

Для синхронізації пристрою потрібна встановлена спеціалізована програма та необхідний драйвер.

Висновки. Потужні світлодіоди УФ спектра дозволять доступним способом проводити дезінфекцію на ріжучій частині ультразвукового хірургічного інструменту. В роботі розроблено модель ультразвукового хірургічного інструменту та методику дезінфекції для знищення збудника інфекції на ріжучій частині ультразвукового хірургічного інструменту.

\section{Список літератури}

1. Копчак А. В., Рибак В. А., Марухно Ю. І. Патогенез і принципи лікування вогнепальних поранень щелепно-лицевої ділянки в умовах багатопрофільного закладу. Медииина неотложных состояний. 2015. № 7. C. $94-105$.

2. Хірургія військова та надзвичайних ситуацій: метод. вказівки. Тема 1: Вогнепальні поранення та їх лікування. Харків: ХНМУ, 2013. 25 c.

3. Гринюк С. В., Лебединська Н. Ю. Особливості проведення бактеріального контролю за післяопераційними ускладненнями ран у хірургічних хворих. Медичні перспективи. 2011. T. XVI, № 1. С. 65-67.

4. Вільцанюк О. А., Лутковський Р. А., Хуторянський М. О. Нові підходи до профілактики нагноєння післяопераційної рани. Харківська хірургічна школа. 2011. № 4. С. 22-25.

5. Семенов Г. М. Современные хирургические инструменты. Санкт-Петербург: Питер, 2013. $352 \mathrm{c}$.

6. Спосіб створення ультразвукових коливань в хірургічному інструменті: пат. України на корисну модель № 116996. / К. В. Базіло,
Ю. Ю. Бондаренко， В. М. Заїка， Ю. А. Петрушко, Л. О. Федорук; № 201613588 від 29.12.2016; опубл. 12.06.2017, Бюл. № 11.

7. Застосування п'єзоелектричних елементів в ультразвуковій хірургії / К. В. Базіло, Ю. Ю. Бондаренко, В. М. Заїка, Ю. А. Петрушко, Л. О. Федорук. Вісник Черкаського державного технологічного університету. Серія: Технічні науки. 2016. № 4. C. 53-56.

\section{References}

1. Kopchak, A. V., Rybak, V. A., Marukhno, Yu. I. (2015) Pathogenesis and treatment approaches in gunshot wounds of the maxillofacial area in specialized multidisciplinary hospital. Meditsina neotlozhnyih sostoyaniy, No. 7, pp. 94-105. [in Ukrainian].

2. Military and emergency surgery: guidelines. Issue 1: Gunshot wounds and their treatment (2013). Kharkiv: KhNMU, 25 p. [in Ukrainian].

3. Hrynyuk, S. V., Lebedyns'ka, N. Yu. (2011) Peculiarities of bacterial control over postoperative complications of wounds in surgical patients. Medychni perspectyvy, vol. XVI, No. 1, pp. 65-67 [in Ukrainian].

4. Viltsanyuk, A. A., Lutkovskiy, R. A., Khutoryanskyi, M. A. (2011) New approaches to the prevention of postoperative wound suppuration. Kharkivska khirurhichna shkola, No. 4, pp. 22-25 [in Ukrainian].

5. Semenov, G. M. (2013) Modern surgical instruments. St. Petersburg: Piter, 352 p. [in Russian].

6. Bazilo, C. V., Bondarenko Yu.Yu., Zaika V.M., Petrushko Yu.A., Fedoruk L.O. (2017). Method of formation of ultrasonic oscillations in a surgical instrument. Patent of Ukraine No. 116996. [in Ukrainian]

7. Bazilo C. V., Bondarenko, Yu. Yu., Zaika, V. M., Petrushko, Yu. A., Fedoruk, L. O. (2016) Application of piezoelectric elements in ultrasonic surgery. Visnyk Cherkaskogo derzhavnogo tehnologichnogo universitetu. Seria: Tehnichni nauky, No. 4, pp. 53-56 [in Ukrainian]. 
C. V. Bazilo, Ph.D. (Eng.), associate professor,

V. M. Zaika, Ph.D. (Eng.),

Yu. Yu. Bondarenko, Ph.D. (Eng.), associate professor

Cherkasy State Technological University

Shevchenko blvd, 460, Cherkasy, 18006, Ukraine

\section{DEVELOPMENT OF DISINFECTION SYSTEM}

OF ULTRASONIC SURGICAL INSTRUMENT

Prevalence of gunshot wounds in modern world is associated with criminalization of society, terrorist threats, increase of a number of local military conflicts and civil unrest. Search and development of methods for reducing blood loss, accelerating the healing of postoperative wounds and scars resorption is an important goal of modern surgery, the solution of which is facilitated by the use of ultrasound. The use of ultrasonic surgery in military medicine and the use of piezoelectric elements as the source of ultrasound are perspective.

Primary surgical treatment of wounds is the main method of preventing the development of severe infectious complications of gunshot wounds. When using an ultrasonic surgical instrument, an urgent task is to disinfect it before and after the operation.

The purpose of this work consists in the development of disinfection method for destruction of pathogen of infection on the cutting part of ultrasonic surgical instrument.

In the paper a diagram is worked out and the design of tension transformer is conducted for ultraviolet emitters, the dock-station is constructed for a mobile ultrasonic surgical instrument for its loading and the process of desinfection. The model of ultrasonic surgical instrument and disinfection method for destruction of pathogen of infection on the cutting part of ultrasonic surgical instruments are developed.

The worked out surgical instrument is mobile and autonomous, that is provided by the use of Li-ion accumulators, reliable and has considerable tenure of employment of active elements from piezoceramics, comfortable in exploitation and simple in a management due to the use of ergonomic handle.

Keywords: ultrasound, surgical instrument, ultraviolet radiation. 